\title{
Understanding the Aspirations of Farming Communities in Developing Countries: A Systematic Review of the Literature
}

\author{
Ravi Nandi $^{1}$ (D) Swamikannu Nedumaran ${ }^{1}$ (D)
}

Accepted: 12 May 2021 / Published online: 27 May 2021

(c) The Author(s) 2021, corrected publication, 2021

\begin{abstract}
This study surveys the panorama of research on the importance of aspirations of farming communities, identifies research gaps and prospects for future research. The analysis of 22 studies identified from 419 research articles sheds light on the relationships between aspirations, agriculture, women's empowerment, poverty, and rural youth. Aspirations of the rural poor play a significant role in shaping their activities and investments. Furthermore, the poor and those who are exposed to natural disasters are more likely suffering from aspiration failure and their resilience needs to be built. Specifically, women's empowerment could be supported through raising aspirations. In addition, intergenerational aspirations and corresponding investment plans in agriculture are in absolute contrast and parental desires and their children's aspirations do not align. Overall, development program-specific research is needed to determine policies and programs that successfully and cost-effectively raise the rural poor's aspirations and thereby improve livelihoods in developing countries.
\end{abstract}

Keywords Farming communities · Aspiration - Systematic literature review · Developing countries

\section{Résumé}

Cette étude vise à sonder le monde de la recherche sur l'importance des aspirations de la communauté agricole, à identifier les lacunes en matière de recherche et les perspectives pour de futures études. L'analyse de 22 études identifiées à partir de 419 articles de recherche révèle la relation entre les aspirations, l'agriculture,

Ravi Nandi

n.ravi@cgiar.org; nandi999hu@gmail.com

Swamikannu Nedumaran

s.nedumaran@cgiar.org

1 Research Program - Innovation Systems for the Drylands (ISD), Markets, Institutions, Nutrition $\&$ Diversity, International Crops Research Institute for the Semi-Arid Tropics (ICRISAT),

Patancheru, Hyderabad, Telangana 502324, India 
l'autonomisation des femmes, la pauvreté et la jeunesse rurale. Premièrement, les résultats font état des aspirations des populations rurales pauvres dans le contexte du développement agricole et rural et de la manière dont ces populations jouent un rôle important dans l'élaboration de leurs activités et investissements. Deuxièmement, les populations pauvres et celles qui sont exposées aux catastrophes naturelles sont les plus susceptibles de voir leurs aspirations échouer. La résilience des personnes exposées à ce risque doit être renforcée pour aider les personnes touchées à se remettre des chocs négatifs. Troisièmement, le fait d'élever leurs aspirations est un moyen d'autonomiser les femmes qui vivent en milieu rural. Quatrièmement, les aspirations des différentes générations et les plans d'investissement dans l'agriculture sont en totale opposition; il existe un fossé entre les désirs des parents et les aspirations de leur enfant. Enfin, des recherches sur les programmes de développement sont nécessaires pour déterminer quelles politiques et quels programmes sont les plus efficaces et les plus rentables pour élever le niveau d'aspiration des populations pauvres rurales pour l'amélioration de leurs moyens de subsistance dans les pays en développement.

\section{Introduction}

The aspirations of the rural poor are increasingly being recognized as an essential dimension of their well-being (Kosec and Mo 2017). It is imperative to understand and nurture these aspirations if governments want to improve the well-being of the poor. Populations with high aspirations subsequently visualize and engage in forward-looking behavior (Dalton et al. 2015; Kosec and Mo 2017), whereas low aspirations among the rural poor lead to reduced efforts and fewer investments for bringing about a prosperous future. When the poor fail to see a better tomorrow in which their well-being would be much higher than it is today, they do not take action to improve their future, and consequently become even more stuck in a poverty trap (Duflo 2013). Besides, aspirations are not merely expectations of what the future will be like; individuals could aspire to outcomes that might be possible only if barriers were removed or if they altered their behavior. Genicot and Ray (2017) report that aspirations are broadly socially determined, and that people form aspirations by seeing them within their cognitive window. However, there is no single external or internal determinant of aspiration formation. The dimensions to which an individual could aspire are potentially infinite; however, income, wealth, education, and social status are the central dimensions that capture a large share of what the rural poor aspire to (Kosec et al. 2016). Recent research in Pakistan revealed that income, assets (wealth), status in society, education for children, and security are typical aspirational themes for rural communities that are involved in agricultural activities (Kosec and Mo 2017).

Besides various factors that determine behavior, aspirations also shape economic behavior (Camerer et al. 1997; Maertens 2011; Mo 2012) and as well as political and community engagement (Kosec and Mo 2017). They might therefore significantly affect agricultural productivity, livelihoods, and rural welfare. The aspirations of the rural poor play a significant role in shaping their livelihood activities and investments; it is therefore important to study these relationships so that appropriate policies can be 
designed to nurture their aspirations. The aspirations of farmers may influence the agricultural inputs and investments they select, which could, in turn, lead to increased productivity. Mausch et al. (2018) acknowledged that aspirations play a role in influencing short and medium-term decisions and have a potentially great influence on technology adoption. Pertinent questions for development planning emerge from these considerations and findings. For example: What are young people's aspirations when they leave family farming? What are the aspirations of adolescents in a rural setup? And what are the aspirations of women when they are increasingly responsible for farming as men migrate for jobs elsewhere? Addressing these questions can help to understand the mindset of the rural poor in the context of agricultural development.

\section{Study Objective}

Research on the aspirations of farming communities requires systematic deliberation, because aspiration studies in developing countries to date have mainly been confined to education and professional (occupation) studies (Giuliani et al. 2017). Consequently, it is important to understand the aspirations of those rural communities that have chosen to remain in agriculture. Therefore, the motivation for this systematic literature review was to identify and analyze the quality of the currently available literature on the aspirations of farming communities (mainly farming households, farming women, the landless, and young people in agriculture) that are related to livelihood outcomes. Based on the resulting insights, we will identify possible specific research gaps and methodological. Ultimately, the aim of our study was to suggest appropriate policies, practices, and programs for the improved welfare of farming communities.

The rest of the paper is organized as follows. We briefly introduce the conceptual framework which links the concept of aspirations and its multiple drivers to the outcomes through the material, social and structural realities confronting farming communities in developing countries, in "Conceptual Framework" section. In "The Importance of Aspirations in Agricultural Development?" section, we present the importance of aspirations in agricultural development following the relevance of aspiration studies in the context of young people moving away from agriculture (migration), aging farmers, feminization of agriculture, and agrarian distress. The methods, including screening of the literature, study selection, data synthesis and quality determination of identified articles are presented in "Material and Methods" section. "Results" section presents and discusses the results of the analysis, while "What have We Learned?" section provides a summary of lessons learned from the reviewed studies, concluding remarks, implications for policy, study limitations and identified future research needs.

\section{Conceptual Framework}

The conceptual framework used here links the concept of aspirations and its multiple drivers to the outcomes through the material, social and structural realities confronting farming communities in developing countries. We conceptualize farmer's aspirations in agricultural development based on four ideas: aspiration window and 


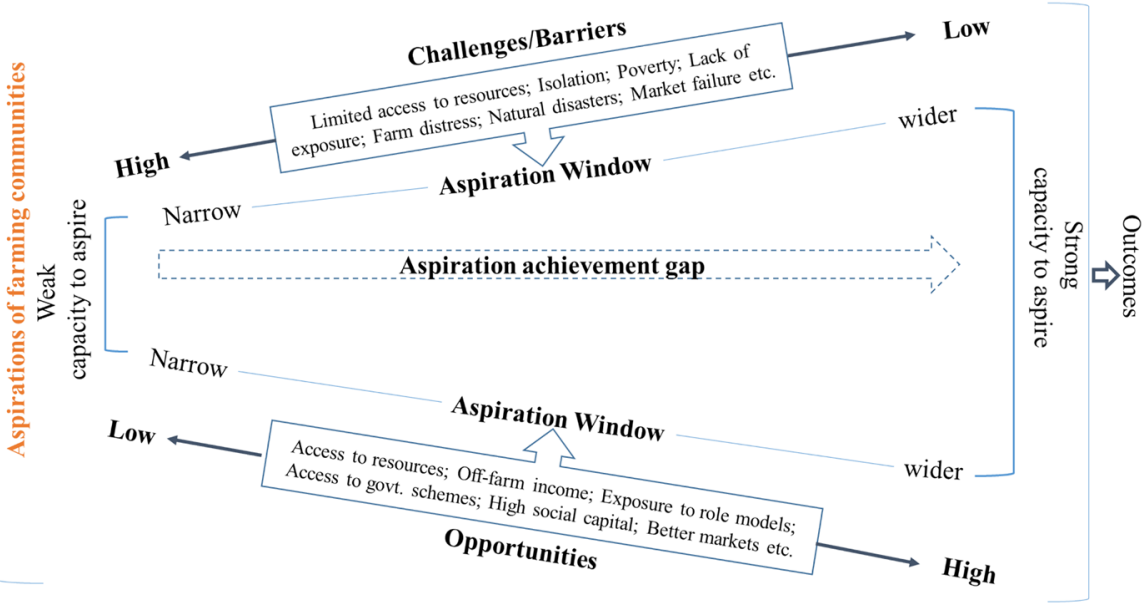

Fig. 1 Conceptual framework linking aspirations and its multiple drivers to outcome

aspirations gap ( $\mathrm{Ra}, 2006)$ as well as capacity to aspire and aspirations failure (Appadurai 2004) (Fig. 1). Ray (2006, p. 1) defines an aspiration window as 'an individual's cognitive world, her zone of "similar", "attainable" individuals'. An individual draws his/her aspirations from the lives, ideals and achievements of those around who serve as role models. Aspiration gaps then are the difference between what an individual aspires to and what he/she already has, or is able to achieve. Such gaps affect future-oriented behavior and in fact can lead to what Appadurai (2004) calls a 'weak capacity to aspire' or 'aspiration failures'. He describes this as a situation when individuals fail to set ambitious goals or targets, do not proactively invest in them and hence also fail to achieve them. While aspirations reflect personal interests and capacities, and may be rooted in an individual's aspiration 'window', they are mediated by a range of factors operating at multiple institutional scales. These include material or economic deprivation (of the individual or household), social relations within and beyond the communities including discrimination based on identity (e.g. gender, caste), and wider structural factors including market arrangements and state policies (Rietveld et al. 2020). Based on the empirical studies identified through systematic review, we discuss that appropriate policies are needed to raise the aspirations of farming communities in particular poor farmers to contribute towards the agricultural development in developing countries.

\section{The Importance of Aspirations in Agricultural Development?}

Research from Ethiopia and Pakistan revealed that high-aspiring individuals engage in forward-looking economic and political behavior that tends to benefit their households and society (Kosec and Mo 2017; Tanguy et al. 2014). Low aspirations and economic vulnerability are closely linked to poverty and poverty traps (Kosec and Mo 2017). The aspirations of rural youth and the factors that contribute to their 
formation should, therefore, be of concern not only to the young people themselves, their families, and their communities, but also to all those who are interested in agricultural policy development. Several developmental interventions (see Appendix 1) demonstrated that interventions could raise the aspirations of the target population (Riley 2017). Knowledge about the aspirations of rural communities that engage in farming is very important in developing countries, for the reasons discussed below.

\section{Aging Farming Population, Urban Migration, and Agriculture}

Apart from the contribution of family values and emotional support to the formation of aspirations (Bowles et al. 2005; Jacqueline et al. 2007), socioeconomic conditions of individuals are also an important determinant of aspirations. An aging population and rural-urban migration are becoming a significant concern for policymakers worldwide, both in developing and developed countries (UNDESA 2015). The impact of an aging population on agriculture is most significant (Zou et al. 2018). Among the regions globally, Sub-Saharan Africa has achieved the highest rate of agricultural production growth and productivity since 2000 (Yeboah and Jayne 2018). However, the future of agriculture in the region is jeopardized due to an aging farming population and waning interest of rural youth in agriculture (Jöhr 2012; BBC 2019). As reported by FAO, the average age of African farmers is about 60 , in spite of the fact that $60 \%$ of the population is under 24 years of age. In addition, many farmers are women who lack access to productive resources, while large number of rural youth are moving towards cities for a better livelihood (FAO 2014, p. 2). A similar trend is observed in major countries of Asia. Based on the World Bank report 2018, half of the Indian population will live in urban centers by 2050 . It is estimated that the percentage of agricultural workers in the total workforce might decrease from $58.2 \%$ in 2001 to $25.7 \%$ by 2050 (Press Information Bureau 2018). There are now nearly nine million fewer farmers than in 2001 , for the first time during the past 40 years, the absolute number of cultivators has declined in India (Rukmini 2013). A study from Kenya reports $65 \%$ of the rural youth opted for having their own business rather than agriculture as their preferred livelihood option. However, LaRue et al. (2021) concluded that artificially forcing youth to choose between alternative livelihood options may disguise nuanced aspirations as open ended questions revealed that most youth envision a mixed livelihood. Therefore, the continued importance and sustainability of the agricultural sector will rely on qualified and competent youth who can involve themselves in farming.

\section{Women and Agriculture}

In recent years, especially in rain-fed or climatically vulnerable regions, male members of farming households have been migrating to urban centers for non-farm employment, leaving female members of the household to take care of the agricultural activities (FAO 2018). More than 400 million women are involved in farm work globally although they do not have equal rights in land ownership in more than 90 countries (Pachauri 2019). Women engage in land preparation, sowing, weeding, 
harvesting, and other labor-intensive processes, in addition to their household chores (Pachauri 2019). Women's contribution to agriculture and its productivity could be much higher if they had equal access to essential resources and services, such as credit, land, and training, and representation in decision-making. A study from Makueni county in Kenya revealed, in the absence of men and in the presence of restrictions on women's movement out of rural life, women are increasingly engaged in farm management decisions/labor, and women's aspirations centered towards commercializing their farms (Crossland et al. 2021). There is a need for research to understand the difficulties experienced by women in farming, and their aspirations while encouraging their participation in decision-making (World Bank 2017).

\section{Natural Disasters, Agriculture, and Aspirations}

The frequency and distribution of natural disasters are increasing and significantly affecting livelihoods and economies (Kosec and Mo 2017). Such disasters often negatively affect agriculture, infrastructure, trade flows, and ultimately the livelihood basis of the rural poor which in turn affects food security more widely. Rural communities in vulnerable regions, especially in developing countries, are most exposed to agriculture-related risks. This is particularly true for those who are dependent on agriculture and wage labor as they are more negatively affected by natural disasters especially if they do not have non-agricultural income sources to buffer these shocks (Kosec et al. 2014a). Natural disasters not only reduce the income and assets of the poor today, they affect their resilience to bounce back and contribute to lower aspirations for the future (Kosec et al. 2014a). Dilley et al. (2021) highlighted that understanding aspirations of farmers also helps in understanding their challenges and potentialities that matter to the farmers. This can then be used to developing more responsive development interventions focused on the perception and aspirations of the farmers. Therefore, there is need for understanding the aspirations to develop adaptation strategies to quickly restore the livelihoods of the poor, and also to raise the aspirations of the poor in affected areas. If the rural poor have high aspirations, it might reduce future poverty and improve resilience by leading to more highly productive investments (Kosec et al. 2014b).

\section{Material and Methods}

\section{Screening the Literature and Study Selection}

The search was conducted from January to April 2019 using four databases: Web of Science, IFPRI eLibrary, MDPI, and CAB Abstracts. These databases hold a wide range of peer-reviewed literature, research reports, policy notes, working papers, conference papers, and case studies covering different themes in the social science literature. We applied a combination of search terms relevant to the concepts of "aspirations" and "rural poor" (Table 1). Each set of terms was initially applied without specifying any countries, and then narrowed down to developing countries. 
Table 1 Search topics and terms used in the systematic review

Keyterms

"Youth \& agriculture"; AND "Rural youth aspirations"; "Youth and aspirations"; AND Youth and farming; AND "Aspirations and agriculture"; AND "Farm parent's aspirations"; AND "Household aspiration"; AND "Farmer's aspirations"; AND "Women's aspirations and agriculture"; AND

"Future farmer"; AND "Adolescent aspirations and agriculture"

The intention was to survey the range of research articles on the topic; however, it is possible that not every relevant article was identified.

For the first stages the search terms were used to screen the overall topic, abstracts, and keywords. In preliminary searches, we tried a comprehensive set of searches around the theme by using combinations of words. However, we found that a topic such as aspirations commonly resulted in articles that included alternative terms such as "desire," "ambition," "aim," "wish," or "dream" in combination with our specified search terms. In all of the database searches, we confined ourselves to literature published in the English language. After preliminary searches in all databases, bearing in mind the relevance and availability of the literature, we restricted our search to the literature published between the years January 2000 and April 2019. The articles identified covered a wide range of topics relating to "aspirations" but they were predominantly in the context of education and migration studies. We included peer-reviewed publications, research reports, policy notes, working papers, conference papers, and case studies. Grey literature, opinion pieces, and review articles were excluded, with the exception of a few articles that were relevant for the section on measuring aspirations (Bernard and Taffesse 2012, 2014; Ray 2006). All the articles that we identified were imported into the free-access reference manager software Zotero, and duplicate articles were removed. After an initial title screening, shortlisted titles and abstracts were screened by the lead researcher. After excluding aspiration studies within the context of education and migration, which is a widely researched area in developing countries, we realized that aspiration studies within the context of farming communities within rural set up is a relatively emerging field. Twenty-two studies were included (see Appendix 1) and are discussed in this review.

\section{Data synthesis and Quality Determination}

Upon screening the 22 full texts, data synthesis was carried out by the authors. Information on the type of study, author(s), type and year of publication, study location (country), research design, objective(s) of the study, participants, and outcomes was synthesized for each of the included studies. A summary of these studies is presented in Appendix 1. Because the studies varied so widely in terms of context, scope, study design, and method, it was a significant challenge to determine their quality and compare outcomes. Qualitative research generally does not focus on measurable outcomes, a principle that is broadly important in systematic reviews. Furthermore, the Department for International Development (DFID) framework that is generally used to examine the strength of both 
Table 2 Quality determination criteria ( Adapted from Yosef et al., 2015)

\begin{tabular}{|c|c|}
\hline Does the study... & Score \\
\hline Acknowledge existing research? & 1 point \\
\hline Have a conceptual framework? & 1 point \\
\hline Have an enquiry question? & 1 point \\
\hline Present a hypothesis? & 1 point \\
\hline Link to raw data? & 1 point \\
\hline Recognize limitations? & 1 point \\
\hline Identify research design? & 1 point \\
\hline Identify research method? & 1 point \\
\hline Explain why it uses a specific design or method? & 1 point \\
\hline Use a well-suited indicator? & 1 point \\
\hline Outline results that are generalizable? & 1 point \\
\hline Use instruments that are reliable for measuring aspirations? & 1 point \\
\hline $\begin{array}{l}\text { Contain signposting (the text clarifies key aspects, such as aim, structure, and conclusion, and } \\
\text { shows connections between sentences and paragraphs)? }\end{array}$ & 1 point \\
\hline End with a logical conclusion? & 1 point \\
\hline \multicolumn{2}{|l|}{ Is the study internally valid? (up to four points) } \\
\hline \multicolumn{2}{|l|}{ Internal validity was based on the study design used } \\
\hline Randomized controlled trials & 4 points \\
\hline Quasi-experimental studies & 3 points \\
\hline Longitudinal studies & 2 points \\
\hline Descriptive or cross-sectional studies & 1 point \\
\hline High-quality/detailed aspirations & 3 points \\
\hline
\end{tabular}

quantitative and qualitative pieces of evidence depends on which quality determination and grading scales have been used (DFID 2014). The framework is used in the literature for grading evidence that emerges from systematic reviews (Yosef et al. 2015). The framework has been used as part of our systematic review with necessary adaptations. As shown in Table 2, the point scores given to studies were based on the study design used and therefore greater importance has been given to internal validity by study design. Therefore, quantitative study designs using randomized controlled trials (RCTs) or quasi-experimental study designs received higher point scores than descriptive, longitudinal studies.

Overall, the systematic literature review identified both quantitative and qualitative research. Of the 22 articles, 16 were quantitative and six qualitative studies. The quality determination criteria developed by Yosef et al. 2015 were adapted to determine the quality of the selected articles. Quality determination, which was based on the DFID framework, assigned point scores based on the criteria shown in Table 2. Of the 22 studies, nine studies received a point score between 13 and 18, and were marked as "I," of high quality. Eight studies received point scores between seven and 12, and were marked as "II," of medium quality. Five of the 
studies received fewer than six points on the grading scale, and were marked as "III," of poor quality (see Appendix 1).

\section{Results}

This section briefly describes the findings from our review and categorizes them based on aspiration studies within the context of agricultural development for livelihood outcomes.

Of these 22 studies identified in the literature review and screening, 20 had a specific national or regional focus in Africa and Asia; the other two studies are multi-country studies (Fig. 2). Only two of the 22 articles were published before 2012, and the highest number (six articles) were published in 2018 (Fig. 3). A Preferred Reporting Items for Systematic Reviews and Meta-Analyses (PRISMA) process chart is shown in Fig. 4.

Most of the studies in Ethiopia and Pakistan are of high quality (their quality determination category is "I") whereas most of the studies in India are of medium to poor quality (their quality determination categories are "III" \& "II"), with the exception of one study by Raghunathan et al. (2018). A summary of the 22 studies included and their main findings is presented in the next sub-sections.

\section{Measuring Aspirations}

Aspirations, like any other attitudinal traits, are not directly observable (Bernard and Taffesse 2012). From the literature, it is observed that there are three alternative

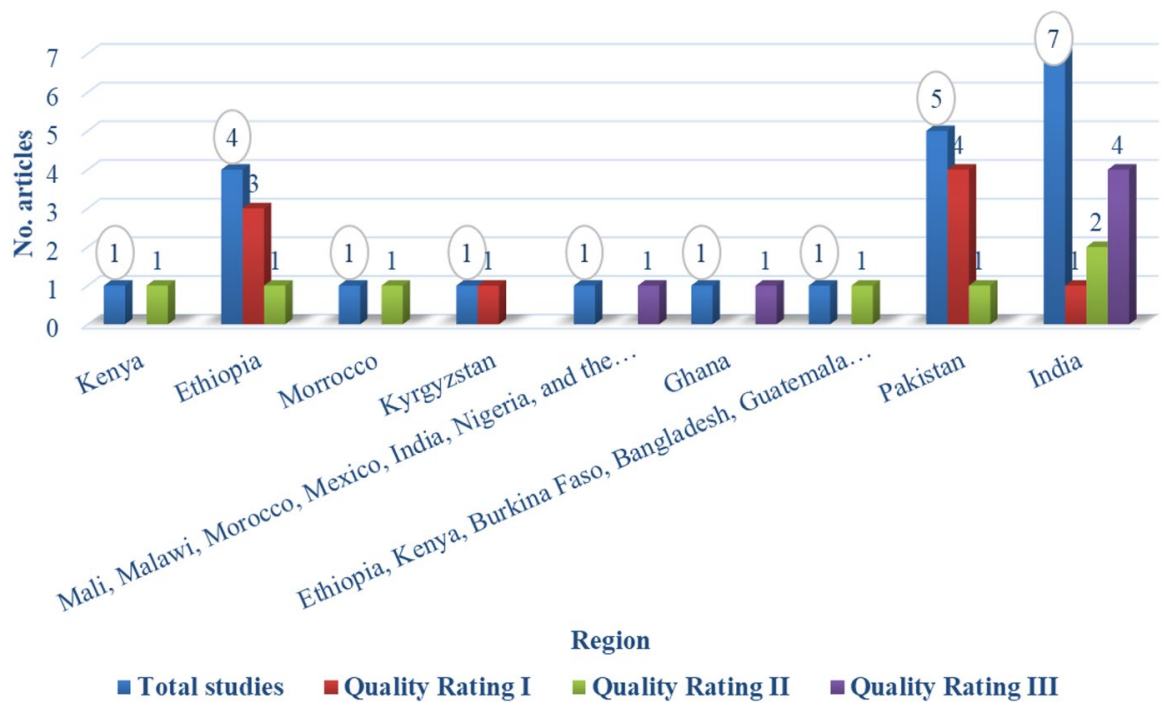

Fig. 2 A summary of the shortlisted papers. Source: Authors own compilation. For the quality assessment criteria, refer to Table 2 


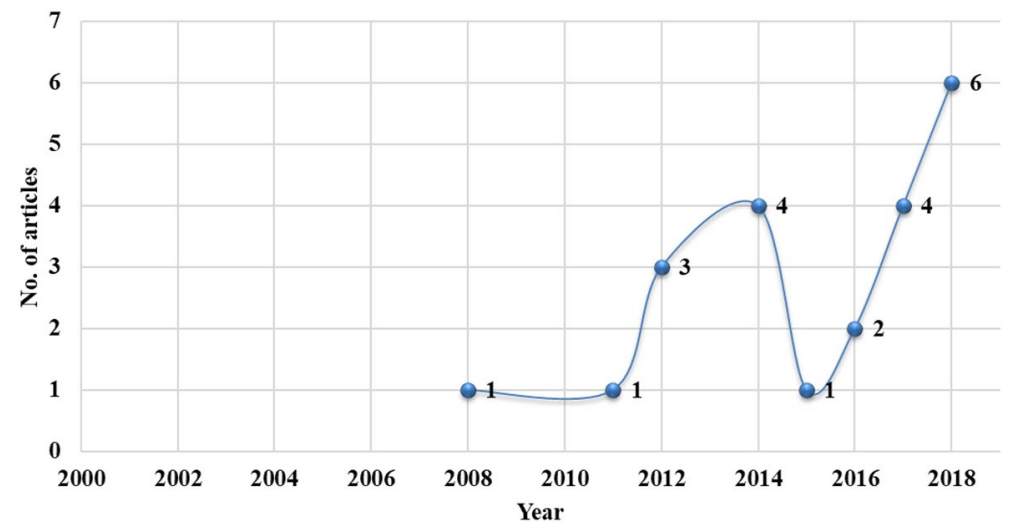

Fig. 3 Identified research articles according to the year of publication

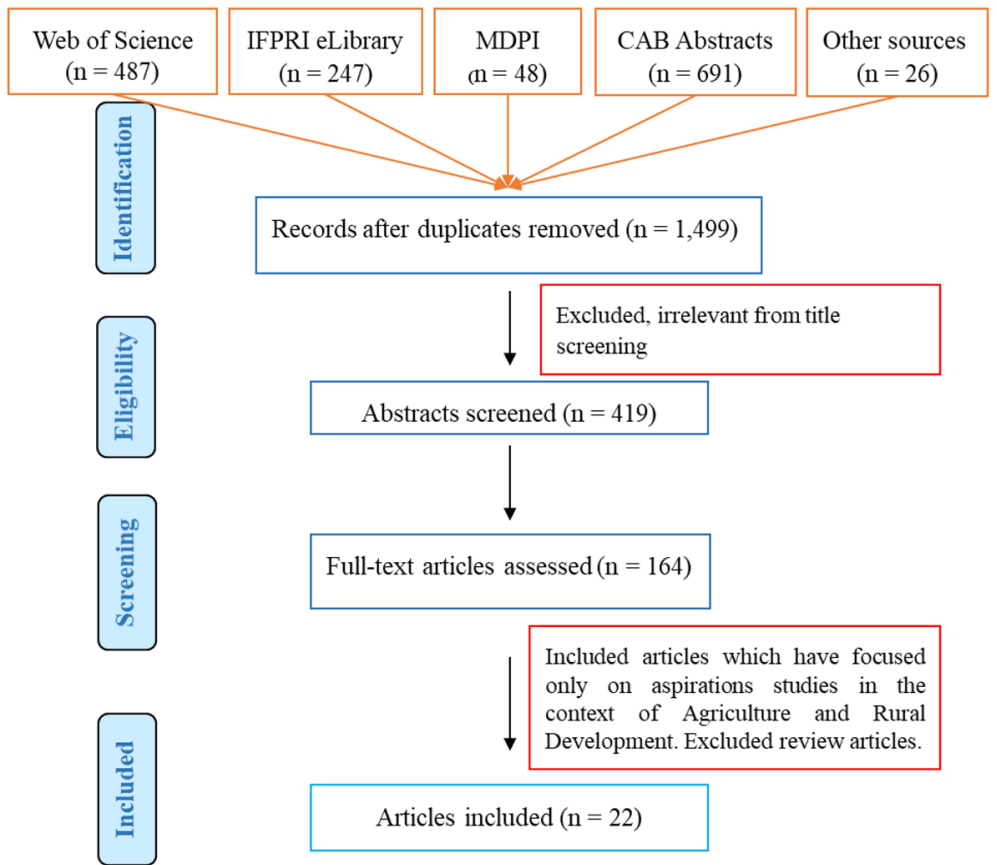

Fig. 4 Flowchart of the systematic screening process

methods to observe aspirations, namely, the direct method, the indirect method, and the construction of a summary measure called an aspiration index. Through the indirect method, aspiration levels are measured by combining the set of individual's aspiration determinants such as low aspiration linked to low investments. Similarly, through the direct method, asking an individual directly about their aspirations towards specific dimensions such as education, occupation, etc. Bernard and 
Taffesse (2012) opine that a direct approach can generate good quality data, provided implemented carefully and considering the potential sources of bias. Through direct and indirect methods, it is possible to measure only a single dimension at a time. However, in some cases where multiple interlinked aspiration dimensions are to be measured, the construction of a summary measure (aspiration index) is useful. Across the articles we reviewed, the indicators used to measure aspiration vary, restricting the comparability of the multiple ad hoc experimental tools to gauge aspirations. Of the 22 studies that examined aspirations towards different dimensions, 12 studies have employed econometric methods (indirect), six studies have employed qualitative and descriptive methods (direct) and four studies were based on an aspiration index.

It is therefore important to identify a simple measurement instrument that bridges distinct dimensions aggregated through individually specific weights from the literature, and then make it available for use. Although such efforts are common in the field of psychometrics, this is not the case for economics in the context of agriculture and development. Most of the high-quality "quantitative studies" on aspirations that are available in the literature (Bernard et al. 2008; Giuliani et al. 2017; Kosec et al. 2012, 2016; Kosec and Khan 2017; Kosec and Mo 2017; Raghunathan et al. 2018) measure an individual's aspiration levels based on the aspiration index developed by Beaman et al. (2012) and Bernard and Taffesse (2012, 2014). This index offers a straightforward attempt to measure aspirations, it is simple to use, and consistent with the purpose of the descriptive or analytical analysis. It is valid, and reliable instrument to measure aspirations within standard surveys. In fact, the questions that the authors used are similar to those used in most of the literature studying aspirational and educational attainments. However, for any of the attitudinal indicators, the validity and reliability of the individual components and their aggregates remain to be tested.

\section{Aspirations and Agricultural Development}

A quantitative study to examine how well aspirations predict agricultural input choice, crop yields, and individuals' propensity to make forward-looking decisions was carried out by Kosec et al. (2016) in Pakistan. The findings suggest that aspirations vary widely across rural Pakistan, and the authors identified several characteristics that predicted the aspiration levels of rural communities that were vulnerable to aspiration-induced poverty traps. Women demonstrated lower aspirations than men, uneducated individuals had lower aspirations than those with some education, and rural non-farm workers had higher aspirations than agricultural wage laborers. The evidence from the experiments indicated that having higher aspirations was associated with higher crop yields, higher rates of adoption of fertilizers, pesticides, and herbicides, lower crop losses, higher savings, more use of credit, and higher rates of operation of non-farm enterprises. Overall, the results suggest that having higher aspirations might motivate farmers to invest more in agri-inputs, especially fertilizers that increase crop productivity. The use of such inputs might be inhibited 
by aspiration failure. ${ }^{1}$ This is like the chicken-egg situation, where the lower aspirations may be based on a lower ability to use inputs which is based on social relations and leads to downward adjustments of aspirations to the context. The results also highlight that mediating pathways that build confidence in the judicial system might be an essential institutional investment to help raise the aspirations of the rural poor. Cognitive factors such as high self-esteem and having an internal locus of control, and other factors such as literacy patterns, gender inequality, and occupational inequalities can be influenced by effective policies. A study by Verkaart et al. (2018) in Kenya asked pertinent research questions: To what extent are rural households "really" farmers? What are household livelihood aspirations, and how to better understand the rural livelihood decision environment? The objective was to understand rural aspirations for agricultural technology development and transfer. The results revealed that most of the households belonged to the mixed-income and non-farm clusters while full-time farmers were only a minority. Further, the results revealed that the major share of full-time farmers and mixed income households characterized themselves as farmers, even most farm workers and non-farm households self-identified as farmer households. The study cautioned against calling all households with farm activity as farmers as it may decrease the match between demands and technology development.

Further, the study identified household livelihood aspirations. Based on these pieces of evidence it is recommended to distinguish carefully distinguishing between rural households, even beyond farming and non-farming by considering income portfolios and household aspirations, when targeting agricultural interventions. It is better to listen to those whom we call farmers to be able to offer innovations that meet their realities. Agarwal and Agarwal (2016) carried out a similar study focusing on farm households in India by surveying 51,770 rural households, involving 286,503 individuals dwelling in 6,638 villages. The aim was to understand agrarian transitions by asking what farmers feel about farming. Do people cultivate based on choice or lack of options and how do they like farming.? The study reported that $76 \%$ of the farmers were dissatisfied with farming and operate one hectare or less, compared to 1.36 ha among satisfied farmers. Women tend to dislike farming more than men, and younger respondents dislike farming and have aspirations beyond farming. Some of the reasons reported for dissatisfaction in farming were the inherent risk, low profitability and low social status. They however continue farming because they cannot readily find jobs elsewhere. The study suggests the need for understanding the aspirations of farmers to develop appropriate intervention strategies to help them to overcome constraints, so that they see farming as a viable occupation or exit on their own terms rather than in distress.

Kale et al. (2018) investigated the aspirations and planning of dairy farmers in India. Based on the aspirations of dairy farmers in three major milk-producing states, the study revealed that the average herd size is likely to increase in all the three states. However, the number of dairy farmers is likely to decrease. In the state

\footnotetext{
1 Aspiration failure is a situation in which individuals fail to set ambitious aspirations, nor seek to achieve them and do not proactively invest to improve their situation. Such failures may manifest the individual's fatalism (Bernard et al. 2008).
} 
of Haryana, a Buffalo-based system will probably remain dominant; the number of large-scale crossbred and pure indigenous dairy cattle in farms will probably increase. Maharashtra farmers showed more inclination towards crossbred cattle and wanted to increase the variety of crossbreeds. Similarly, Bell et al. (2017) carried out a discrete choice experiment about the hypothetical purchase of a drip irrigation system with a subsidy program in four selected districts of the Punjab province of Pakistan where the existing subsidy program is helping to boost the low level of technology adoption. Farmers were unaware of the irrigation system's potential or of the benefits that may accrue from its use. The adopters and non-adopters were peers who were exposed to the same information regarding drip irrigation. The results showed that aspirations differed across adopter and non-adopter groups. Aspirations proved to be a better predictors of the valuation of a drip program than existing cropping patterns. Specifically, the results demonstrated that higher aspiring individuals anticipate higher valuation of area coverage and a greater sensitivity to the cost of the system. The intervention program might prove to be more successful in reaching targets for smallholder farmers if their aspirations are identified beforehand.

\section{Aspirations of Rural Youth and Agriculture}

A diagnostic analysis of rural youths' aspirations for life (whether to remain in agriculture or migrate to the city) in the dryland agriculture system of Morocco showed that there is more interest, among male youths to continue agriculture. However, it also showed that increased investments to improve the livelihoods of those rural populations are critical for reducing rural-urban migration (Giuliani et al. 2017). On the contrary, qualitative research in 10 countries (Burkina Faso, Ethiopia, Kenya, Bangladesh, Guatemala, Zambia, Bolivia, Indonesia, Pakistan, and Vietnam) to understand who wants to farm and under what conditions discovered that, despite agriculture being the mainstay livelihoods, it was not a preferred option for the younger generation in rural areas of these developing countries (Leavy and Hossain 2014). The younger population aspired to gain and use formal education to get employment in respected white-collar or professional occupations after leaving family farms. However, higher levels of education did not automatically translate into good jobs, and this affected educational aspirations. Agriculture was seen as a last resort when their education failed to get them into good jobs in urban areas. Further results, particularly from countries such as Ethiopia and Indonesia, showed optimism about the prospects of a career in agriculture, and about how education could contribute to higher productivity. Another similar study in India investigating the predictive factors affecting rural farm youths' decisions to stay in, or leave, the agricultural sector (Nag et al. 2018) revealed that a large percentage of rural farm youths would leave farming in the future. Factors such as smaller and declining landholdings, low prestige or negative attitudes towards farming played a significant role in the decision to leave agriculture in the near future. Furthermore, ensuring food security for their family was found to be the main reason for choosing agriculture as an occupation. Along similar lines, rural youths stated that the need to bring stability to 
their life was the primary inspiration to move into farming after trying one or more other occupations.

Another study conducted in the Bellary and Koppal districts of Karnataka State in India focused on aspirations and problems of rural youths practicing agriculture (Viswanatha et al. 2014). It revealed surprising results-as many as $70 \%$ of rural youths had medium to high levels of aspirations in agriculture, provided existing challenges related to markets, infrastructure facilities, inputs, etc. were addressed. Rural youths' landholding, annual income, use of ICT, extension contact, extension participation, education, and innovativeness had a positive and significant relationship with their aspirations in agriculture. A similar study by Shandilya et al. (2017) examining tribal youths' aspirations towards agriculture and non-agricultural activities in India, highlighted that most of them aspired to take up farming as a source of income. In a study of the aspirations of rural youths towards self-development, Tekale et al. (2015) suggested that agro-based enterprises such as dairy, poultry, goatery, sericulture, and beekeeping training must be targeted towards rural youths to enhance their agricultural aspirations. An analysis by Anyidoho et al. (2012) of the perception and aspirations of youths involved in cocoa farming in Ghana found that, even though farming was not a preferred occupation, farm ownership was generally seen in a positive light. Focusing on the generational succession of family farm in Kenya, very few parents hope for a future in farming for their children and this is in absolute contrast to their individual aspirations and investment plans in agriculture (Verkaart et al. 2018).

\section{Aspirations and Women's Empowerment}

Kosec and Song (2018) conducted an empirical investigation by surveying 2,529 households in Kyrgyzstan to understand the importance of having higher aspirations for the future and their contribution to women's empowerment. The results showed strong evidence that raising aspirations was one way of empowering women. Husbands with higher aspirations foresaw more egalitarian gender relations within their households. However, the wives themselves having higher aspirations was an even more important predictor of women's empowerment. Indeed, higher aspirations on the part of wives predicted a more egalitarian gender attitude for both the husband and his wife, and also women's greater involvement in household decision-making, as agreed by both the wife and husband. By identifying the relationship between aspirations and women's empowerment, the study offers important evidence about the psychological determinants of women's empowerment. The results also reveal that aspirational failures might be partly responsible for the failure to empower women. Furthermore, interventions that aim to raise the aspirations of women might be a promising and low-cost way of changing traditional norms and family roles and expanding opportunities for women. Considering the inherent challenges of changing traditional gender norms, these findings are valuable for policymakers.

Another empirical study used primary data to examine the correlation between the aspirations of rural women regarding income, social status, asset ownership, and the education of their children. It also examined how the gaps between current and 
aspired-to status are associated with individual investments in financial, educational, and social status-related dimensions (Raghunathan et al. 2018). The authors found that reference groups were essential correlates of aspiration formation: aspirations regarding assets and social status were influenced by those who were "wealthier" or more socially connected, respectively. However, income aspirations were influenced almost entirely by current status. Furthermore, groups belonging to Scheduled Caste (SC) and Scheduled Tribe (ST) social classes were almost always negatively associated with women's aspirations. Years of marginalization and exclusion of these groups from better education and paying occupations, and even social circles, might be responsible for the consistently low aspirational levels observed in such groups. Similarly, a policy experiment in India by Beaman et al. (2012) revealed that female leadership affected adolescent girls' career aspirations and academic attainment as parents had lower aspirations for girls than for boys. The gender gap in adolescent academic attainment was removed through female role model effect, and girls spent less time on household chores. Also, the results highlighted no evidence of changes in market opportunities for young women, indicating that the women leaders mainly had a role model effect. Likewise, 25 case studies from the global comparative study "GENNOVATE" which examined young rural young men's and women's work aspirations and pathways in India, Morocco, Mali, Malawi, Mexico, Nigeria, and the Philippines (Elias et al. 2018). They revealed that various gender norms that discriminate against women in agriculture discouraged young women from aspiring to agriculture-related work. Additionally, the norms that portray agriculture as a masculine job restricted women's capacity to learn about and try out innovative practices, limited their agricultural opportunities, and turned their aspirations away from agriculture. If young women are to participate in agriculture, the inequalities they face on the basis of gender and age will need to be addressed. Lastly, two empirical studies in Ethiopia (Bernard et al. 2011, 2008) pointed out that fatalistic beliefs among rural women correlated with lower demand for credit, in terms of loan size, repayment horizon, and productive purposes; indicators of aspiration gaps were also consistent with a small aspiration gap and low self-efficacy.

\section{Aspirations and Poverty}

"Poverty stifles dreams, or at least the process of attaining dreams. Thus poverty and the failure of aspirations may be reciprocally linked in a self-sustaining trap." (Ray 2006).

Kosec et al. (2012) examining the aspirations of 3,500 men and women in rural Pakistan showed that aspirations significantly affected people's lives and decision-making processes. Aspiration levels among rural men and women had real behavioral and economic effects on the poor. In particular, uneducated female agricultural wage laborers had low aspirations, resulting in them falling into a poverty trap. Higher aspirations were associated with behaviors and productive investments that might support growth, such as higher crop yields, intensive input use, and the greater use of agricultural credit. Furthermore, the results indicated that aspirations were significantly lower in those areas most heavily hit by 
unexpected flooding during the 2010 monsoon season. This suggests that even temporary productivity shocks can have lasting impacts on productive outcomes via lower aspirations. The authors stated that the availability of social protection programs could offset the negative effects of floods.

A study using an innovative experimental design (Tanguy et al. 2014) targeted the association between poverty and aspirations in Ethiopia. The study revealed that poor people repeatedly did not invest even when the returns were high, because of low aspirations. They also developed mental models that ignored some options for investment. In this study, the authors attempted to test whether aspirations and futuristic attitudes could be changed by using a new experimental design. The experiment involved exposure to a one-hour documentary in which four people with backgrounds similar to the audience's tell the story of how they improved their economic status. The results indicated that changes in aspirations could be translated into forward-looking behavior. After the intervention, aspirations improved among the treated individuals, but did not change in the control groups. The effects were greater for those individuals who had higher aspirations at baseline. In a similar approach, Dalton et al. (2015) investigated the psychology of poverty and low aspirations, and found that aspiration failure was a consequence of poverty, rather than its cause.

\section{Boosting Aspirations for Resilience Among the Rural Poor}

Kosec and Mo (2017) and Kosec et al. (2014a) investigated the effects of natural disasters on the aspirations of rural households in Pakistan and Ethiopia, and the role of government in addressing those effects. The authors found that natural disasters had a strong negative effect on aspirations which was more pronounced for poorer households. However, such negative impacts could be mitigated through the government's social protection programs. Individuals who were most exposed to agriculture-related risks, specifically those dependent on agricultural wage labor and those without non-agricultural enterprises, were more negatively affected by the floods. The double burden of disasters - which not only deplete the income and assets of the poor today, but also contribute to lower aspirations for the future-demands a double role for resilience strategies to initially restore the livelihoods of the poor, and then raise their aspirations for the future. In such situations, government social welfare or protection programs might raise economic welfare in the short term, and also have a long-term effect by raising people's aspirations for the future. Kosec et al. (2012) conducted a survey among 5,000 households in flood-affected regions in Pakistan where agriculture is the primary source of livelihood, and the security situation is deteriorating, to measure their aspirations. The results showed that individuals generally felt that they had little control over what happened in their lives. Policies aimed at raising aspirations could be focused on specific groups that are most at risk of aspiration failure. Knowledge of what leads to high or low aspirations among the rural poor, and understanding how aspirations affect behavior is useful information for effective, pro-poor policy formulations. 


\section{What have We Learned?}

In the agricultural and rural development landscape, aspirations significantly affect people's lives and decision-making processes. Higher aspirations are good predictors of technology adoption and input choice for higher agricultural productivity. Higher aspirations might motivate farmers to invest more in agriinputs, especially in productivity-enhancing technologies and management practices such as high-yielding varieties (HYVs), fertilizers, and soil and water conservation practices that could increase crop productivity. The adoption of such inputs might be inhibited by aspiration failure. Besides, aspirations vary widely across different sections of society with some groups being particularly at risk of aspiration failure. It is therefore vital for policymakers to understand aspirations, so that they can identify those sections of society where aspirations are systemically low. Understanding of what leads to high or low aspirations among the rural poor and how aspirations influence behavior is useful information for designing effective pro-poor policies. Because of low aspirations, poor people often do not adopt technologies or investments, even when the returns are high.

Higher female aspirations are a crucial indicator of women's empowerment. Therefore, raising aspirations is one way to empower women. Failure to raise women's aspirations may be partly responsible for the failure to empower women. Development programs that aim to raise the aspirations of women might be a high potential and low-cost way to alter ancestral norms and family roles, thereby widening opportunities for women. Evidence shows significant gender gaps in aspirations; unlike their male counterparts, women fail to aspire to aspects that are personally important to them, such as income, asset ownership, education of their children, and the social status. Various discriminatory gender norms discourage young women from aspiring to agriculture-related occupations. There are norms that portray agriculture as a masculine job, discourage women's ability to learn about and try innovative practices, and reduce women's agricultural opportunities. These norms can turn women's aspirations away from agriculture. Opening up avenues for young women in agriculture will require special attention to be focused on the inequalities that they face based on their age and gender. In fact, female leadership positively influences women's aspirations and educational attainment in rural areas.

Aspiration levels among rural men and women have real behavioral and economic effects on the poor. In particular, women, the uneducated, and agricultural wage laborers have low aspirations, resulting in poverty traps. Higher aspirations are associated with behaviors and productive investments that might support growth in agricultural development.

There is a discrepancy between parental desires and children's aspirations about farming as a career choice, and their personal plans and investment in agriculture are in absolute contrast. Despite agriculture being the mainstay of livelihoods, it is not a preferred occupation for the new generation in rural areas of developing countries. Agriculture was seen as a last resort when education failed to get them into good jobs in urban areas. It appears likely that a significant number of rural farm youths will leave farming in the future. 
Natural calamities significantly lower the aspirations of the rural poor. The effects of natural disasters on aspirations are especially negative among the poor compared with wealthier households. Such negative impacts could be mitigated through appropriate social protection schemes by the government.

Aspirations and future-oriented behavior can be altered using innovative interventions (such as exposure to success stories, role models, targeted documentaries, street theatre, puppet shows, and aspiration training sessions) and mass media interventions. Policies could help to develop role models, and thereby open up new opportunities for those sections of society that previously lacked opportunities.

Finally, measuring aspirations is very complex. The instrument developed by Beaman et al. (2012) and Bernard and Taffesse $(2012,2014)$ offers a straightforward method for measuring aspirations. It is simple and consistent with the purpose of descriptive or analytical approaches. The instrument is usable, valid, and reliable for measuring aspirations within standard surveys.

An analysis of the available studies reveals that recent findings related to aspirations have mainly emerged from migration and education studies. There is a scarcity of recent empirical studies on the aspirations of the rural poor who are dependent on agriculture as their livelihood source. Agriculture is the engine of economic growth in many developing countries, even more significantly in Africa, and aspiration studies look very promising to enhance development outcomes. The development of appropriate and effective strategies and programs that focus on the rural poor could positively alter their aspirations, and ultimately lead to better livelihood outcomes.

\section{Concluding Remarks}

The main contributions of this paper are the lessons learned from past studies that show the linkage between aspirations, agriculture, women's empowerment, poverty, and rural youth within the scope of agricultural and rural development. Additionally, we highlight future research areas based on the knowledge gaps that were identified. The paper looks at how the aspirations of the rural poor influence their livelihood outcomes. It is evident that existing studies of aspirations are mainly concerned with education and migration, and mostly relate to the developed world. Such studies are rarely applied to agricultural and rural development, particularly in developing countries. Thus, there is a need for empirical studies to understand the aspirations of the rural poor in order to develop appropriate strategies and effective policies and programs that could improve their welfare. Research on aspirations will result in a better understanding of the life trajectories that rural communities, especially farmers, women, and young people, want to follow. The pathways linking aspirations to agricultural development, women's empowerment, poverty, and resilience to natural disasters have been documented in recent empirical research. Compared with other economically viable indicators, the aspirations of the rural poor are better predictors of household trajectories within agricultural and rural development. Based on the pathways linking aspirations to agricultural development, women's empowerment, poverty, resilience to disaster, and rural youth, several conclusions are significant for future research in this area, particularly for low- and middle-income countries. 
First, the rural poor's aspirations within the context of agricultural and rural development play a significant role in shaping their activities and investments. Thus, the design of appropriate policies and programs could positively alter their aspirations. Second, particular groups are most at risk of aspiration failure. The resilience of the rural poor can be built by helping those who are affected to recover from shocks, such as drought, floods, cyclones, and other negative setbacks, based on their level of aspirations. Third, the aspirations of women are lower than those of men in rural areas and raising women's aspirations is one way of empowering them. Thus, interventions that aim to raise the aspirations of women might be a promising and low-cost way of changing traditional norms and family roles, and expanding their opportunities. Fourth, the evidence of a discrepancy between parental desires and children's aspirations about farming as a career choice must be considered. Empirical studies are needed to help understand young people's aspirations, and ultimately develop appropriate aspiration-raising interventions. Lastly, once empirical studies have increased our understanding of the aspirations of targeted people within the agricultural and rural landscape, specific research will be needed to determine which policies and programs are the most successful and cost-effective for raising the aspiration levels of the rural poor.

\section{Study Limitations}

During the screening process based on a set of keywords, close to 1,000 aspirationrelated articles were excluded because they focused on aspirations in a context other than that of our study. The limitations of this study are a consequence of the limitations in the quality of the studies we reviewed. Furthermore, the measurements of aspirations and indicators used were different across the studies. Therefore, there are limits to the conclusion that have been drawn.

\section{Appendix}

See Table 3. 
Table 3 Overview of studies included in the systematic review

\begin{tabular}{|c|c|c|c|c|c|}
\hline $\begin{array}{l}\text { Sr. } \\
\#\end{array}$ & $\begin{array}{l}\text { Author(s), year } \\
\text { and country of } \\
\text { research }\end{array}$ & Study objective (s) & Data type & Sample size & Main research findings \\
\hline$(1)^{*}$ & \begin{tabular}{|c|} 
(2) \\
\end{tabular} & (3) & (4) & (5) & (6) \\
\hline \multicolumn{6}{|c|}{ Aspirations and agricultural development } \\
\hline 1. & \begin{tabular}{|c|}
$\begin{array}{c}\text { Kosec et al. (2016) } \\
\text { Pakistan }\end{array}$ \\
\end{tabular} & $\begin{array}{l}\text { To investigate how well aspirations predict } \\
\text { agricultural input selection, crop yields, and } \\
\text { individuals' propensity to create forward- } \\
\text { looking decisions. }\end{array}$ & $\begin{array}{c}\text { Cross } \\
\text { sectional and } \\
\text { panel data }\end{array}$ & $\begin{array}{l}3,526 \text { individuals in 2,090 } \\
\text { households. }\end{array}$ & $\begin{array}{l}\text { "Aspirations differed widely across rural Pakistan. Focusing on the groups that are } \\
\text { vulnerable to aspiration-induced poverty traps, the study determined various } \\
\text { characteristics that predicted aspiration levels. } \\
\text { "A number of basic individual and household characteristics shape aspirations. } \\
\text { "A number of communities characteristics predict higher aspirations. High-quality } \\
\text { communities are strong predictors of high aspirations among individuals } \\
\text { "Instilling confidence in the justice system may be an important institutional } \\
\text { investment to raise aspirations. } \\
\text { "Men had higher aspirations than women; the educated had higher aspirations than } \\
\text { those who were uneducated; and rural non-farm workers had higher aspirations than } \\
\text { agriculture wage laborers. } \\
\text { " Having higher aspirations may motivate farmers to invest more in inputs. }\end{array}$ \\
\hline 2. & $\begin{array}{l}\text { Verkaart et al. (2018) } \\
\text { Kenya }\end{array}$ & $\begin{array}{l}\text { To explore rural aspirations and derive lessons } \\
\text { for agricultural technology development and } \\
\text { transfer by asking following questions } \\
\text { 1. To what extent are rural households "really" } \\
\text { farmers? } \\
\text { 2. What are household livelihood aspirations and } \\
\text { are there differences? } \\
\text { 3. How to better understand the complex rural } \\
\text { livelihood decision environment? }\end{array}$ & \begin{tabular}{c|c|} 
Cross \\
sectional data
\end{tabular} & $\begin{array}{l}624 \mathrm{HHs} \text { households were randomly } \\
\text { selected from the village level list of } \\
41 \text { villages those were purposively } \\
\text { selected. }\end{array}$ & $\begin{array}{l}\text { "Findings highlight the relevance of carefully distinguishing between different } \\
\text { types of rural } \\
\text { households. To make the distinction between households, it must be beyond } \\
\text { farming and non-farming households criteria, by further considering differences } \\
\text { within income portfolios but also aspirations. } \\
\text { "Calling all households with farm activity as "farmers" and assuming they have no } \\
\text { other interests, may increase the match between demands and technology } \\
\text { development. } \\
\text { "Very few parents hope for a future in farming for their children. This is in } \\
\text { absolutely contrast to their personal aspirations and investment plans in agriculture. }\end{array}$ \\
\hline 3. & $\begin{array}{l}\text { Kale, Ponnusamy, } \\
\text { Chakravarty, Sendhil, } \\
\text { and Mohammad } \\
\text { (2018) } \\
\text { India }\end{array}$ & $\begin{array}{l}\text { To analyze the present status and future } \\
\text { aspirations of dairy farmers in India by } 2020 \text {. }\end{array}$ & $\begin{array}{c}\text { Cross } \\
\text { sectional data }\end{array}$ & $\begin{array}{l}\text { Stratified Random sampling (16 } \\
\text { states were classified into three } \\
\text { categories namely, highly, } \\
\text { moderately and least dairy } \\
\text { progressive states based on 'Dairy } \\
\text { Progressiveness Index). Sample of } \\
900 \text { dairy farmers: } 300 \text { from each of } \\
\text { three states } \\
\end{array}$ & $\begin{array}{l}\text { The average herd size in all three states studied is likely to increase, although the } \\
\text { number of dairy farmers is likely to decrease. In Haryana, the buffalo dairy system } \\
\text { will remain predominant, but sizeable crossbred and pure indigenous farms will } \\
\text { arise. }\end{array}$ \\
\hline & $\begin{array}{l}\text { Bell, Ward, Ashfaq, } \\
\text { and Davies (2017) } \\
\text { Pakistan }\end{array}$ & $\begin{array}{l}\text { To identify factors inhibiting the adoption of } \\
\text { drip irrigation, by analyzing how respondents } \\
\text { with different socio-economic characteristics }\end{array}$ & $\begin{array}{c}\text { Cross } \\
\text { sectional and } \\
\text { panel data }\end{array}$ & $\begin{array}{l}\text { Discrete Choice Experiment. } 942 \\
\text { households across } 76 \text { sampling units } \\
\text { of the provinces of Sindh, Punjab, } \\
\text { and Khyber Pakhtunkhwa }\end{array}$ & $\begin{array}{l}\text { Farmers' aspirations for cropping systems under drip irrigation were better } \\
\text { predictors of the value of drip systems than current cropping patterns. }\end{array}$ \\
\hline 4. & & $\begin{array}{l}\text { and experiences of drip systems value different } \\
\text { aspects of drip programs. }\end{array}$ & & & \\
\hline \multicolumn{6}{|c|}{ Aspirations of rural youth and agriculture } \\
\hline 5. & \begin{tabular}{|l|} 
Giuliani et al. (2017) \\
Morocco
\end{tabular} & $\begin{array}{l}\text { To understand livelihoods, and also which } \\
\text { factors influence the alternatives and decisions } \\
\text { of rural youth. }\end{array}$ & $\begin{array}{c}\text { Cross } \\
\text { sectional data, } \\
\text { both } \\
\text { qualitative } \\
\text { and } \\
\text { quantitative } \\
\text { data }\end{array}$ & $\begin{array}{l}\text { Purposive sampling, } 106 \text { youths, } \\
\text { three different agricultural } \\
\text { livelihood systems, in different } \\
\text { villages }\end{array}$ & $\begin{array}{l}\text { There was significant interest among male youths in particular to continue and } \\
\text { develop agriculture. However, increased structural investments into improving the } \\
\text { livelihoods of such rural populations are necessary to reduce out-migration. }\end{array}$ \\
\hline 6. & $\begin{array}{l}\text { Leavy and Hossain } \\
\text { (2014) } \\
\text { Burkina Faso, } \\
\text { Bangladesh, Bolivia, } \\
\text { Ethiopia, Indonesia, } \\
\text { Kenya, Guatemala, } \\
\text { Zambia, Pakistan, and } \\
\text { Vietnam }\end{array}$ & $\begin{array}{l}\text { To identify who wants to farm, and under what } \\
\text { situations. } \\
\text { To understand where social, economic, and } \\
\text { environmental conditions are favorable enough } \\
\text { to attract educated young people into farming. }\end{array}$ & $\begin{array}{l}\text { Cross } \\
\text { sectional } \\
\text { qualitative } \\
\text { data }\end{array}$ & $\begin{array}{l}\text { Based on analysis of interviews, } \\
\text { focus group discussion and } \\
\text { household case studies with almost } \\
1500 \text { people in } 23 \text { rural, urban and } \\
\text { peri-urban communities across } 10 \\
\text { countries in low and middle income } \\
\text { Asian, African and Latin American } \\
\text { countries in } 2012 \text {. }\end{array}$ & $\begin{array}{l}\text { The study revealed a widespread and robust desire to gain and use formal education } \\
\text { in respected white-collar or professional occupations. } \\
\text { Results also revealed a big generational difference in educational prospects and } \\
\text { patterns: in general, young people were better educated than their parents, in terms } \\
\text { of upper levels of formal education. Although agriculture was seen as a fallback } \\
\text { option, there was optimism regarding a future career in agriculture. }\end{array}$ \\
\hline 7. & $\begin{array}{l}\text { Nag et al. (2018) } \\
\text { India }\end{array}$ & $\begin{array}{l}\text { To understand which factors predict the future } \\
\text { decisions of rural youth from the eastern states of } \\
\text { India regarding "whether or not to remain } \\
\text { engaged in the agriculture sector." }\end{array}$ & \begin{tabular}{c|c|} 
Cross \\
sectional data
\end{tabular} & $\begin{array}{l}\text { Interview with } 120 \text { rural farm } \\
\text { youths. }\end{array}$ & $\begin{array}{l}\text { Around } 42 \% \text { of rural farm youths would leave farming in the future. Determinants } \\
\text { such as attitude towards dairying and crop farming, landholding, and entry into } \\
\text { farming were significant factors in the decision to quit farming in the near future. }\end{array}$ \\
\hline 8. & $\begin{array}{l}\text { Viswanatha, } \\
\text { Manjunatha, and } \\
\text { Lakshminarayan } \\
\text { (2014) } \\
\text { India } \\
\end{array}$ & $\begin{array}{l}\text { To research the aspirations and problems of } \\
\text { rural youths practicing agriculture. }\end{array}$ & $\begin{array}{l}\text { Cross } \\
\text { sectional data, } \\
\text { mixed } \\
\text { method }\end{array}$ & $\begin{array}{l}120 \quad \text { rural youths practicing } \\
\text { agriculture sampled from } 12 \text { villages } \\
\text { of Bellary and Koppal districts of } \\
\text { karnataka state in India. }\end{array}$ & $\begin{array}{l}\text { Annual income, landholding, education, mass media use, extension participation, } \\
\text { extension contact, and the innovativeness of rural young people were significantly } \\
\text { and positively associated with their aspirations in agriculture. }\end{array}$ \\
\hline 9. & $\begin{array}{c}\text { Shandilya, } \\
\text { Chaturvedi, and } \\
\text { Suryawanshi (2017) } \\
\text { India } \\
\end{array}$ & $\begin{array}{l}\text { To examine the aspiration levels of tribal youths } \\
\text { for agriculture and education. }\end{array}$ & $\begin{array}{c}\text { Cross } \\
\text { sectional } \\
\text { quantitative } \\
\text { data } \\
\end{array}$ & $\begin{array}{l}144 \text { tribal youth from } 12 \text { villages } \\
\text { randomly selected for the interview. }\end{array}$ & $\begin{array}{l}\text { The tribal youths' agricultural aspiration showed a preference for income through } \\
\text { increased crop production; most of the tribal youths aspired to take up farming and } \\
\text { to become agricultural laborers. Overall, tribal youths had a medium level of } \\
\text { aspiration. }\end{array}$ \\
\hline 10. & $\begin{array}{l}\text { Tekale, Mali, and } \\
\text { Shaikh (2015) } \\
\text { India }\end{array}$ & $\begin{array}{l}\text { To gain insight into the aspirations of rural } \\
\text { youths about self-development. }\end{array}$ & $\begin{array}{c}\text { Cross } \\
\text { sectional data, } \\
\text { quantitative. }\end{array}$ & $\begin{array}{l}100 \text { youths randomly selected from } \\
10 \text { villages in Nagpur district of } \\
\text { Maharastra state in India. }\end{array}$ & $\begin{array}{l}\text { Most of the rural youths (51\%) performed medium-level roles in village } \\
\text { development, including agricultural development activities }(56 \%) \text {, social } \\
\text { development activities }(52 \%) \text {, and economic development activities }(43 \%) \text {. }\end{array}$ \\
\hline 11. & $\begin{array}{l}\text { Anyidoho, Leavy, } \\
\text { and Asenso-Okyere } \\
\text { (2012) } \\
\text { Ghana }\end{array}$ & $\begin{array}{l}\text { To analyze how the differences in young } \\
\text { people's backgrounds and their experiences with } \\
\text { cocoa influence their expectations of the role of } \\
\text { cocoa farming in their future. }\end{array}$ & $\begin{array}{c}\text { Cross } \\
\text { sectional } \\
\text { qualitative } \\
\text { data } \\
\end{array}$ & $\begin{array}{l}12 \text { focus group discussions with } 107 \\
\text { young people aged } \quad 16-26 \quad(45 \\
\text { females and } 62 \text { males). }\end{array}$ & $\begin{array}{l}\text { Farming was not a preferred occupation, but farm ownership was generally seen in } \\
\text { a positive light. }\end{array}$ \\
\hline & & & & & \\
\hline
\end{tabular}


Table 3 (continued)

\begin{tabular}{|c|c|c|c|c|c|}
\hline 12. & $\begin{array}{l}\text { Kosec and Song } \\
\text { (2018) } \\
\text { Kyrgyzstan }\end{array}$ & $\begin{array}{l}\text { To determine whether higher aspirations for the } \\
\text { longer term (future) contribute to the } \\
\text { empowerment of women. }\end{array}$ & $\begin{array}{c}\text { Cross } \\
\text { sectional } \\
\text { quantitative } \\
\text { data }\end{array}$ & $\begin{array}{l}6,162 \text { individuals from } 2,529 \\
\text { households survey data is used. }\end{array}$ & $\begin{array}{l}\text { Raising aspirations was found to be one way of empowering women. Higher } \\
\text { aspirations on the part of husbands predicted more egalitarian gender attitudes for } \\
\text { both the wife and the husband. However, higher aspirations on the part of wives } \\
\text { could also be a more important predictor of women's empowerment. }\end{array}$ \\
\hline 13. & $\begin{array}{l}\text { Raghunathan, } \\
\text { Quisumbing, Kumar, } \\
\text { and Cunningham } \\
\text { (2018) } \\
\text { India }\end{array}$ & $\begin{array}{l}\text { To analyze the correlates of aspirations of rural } \\
\text { women about income, asset ownership, and } \\
\text { social station and therefore the education of their } \\
\text { children. To investigate how the gaps between } \\
\text { current and aspiried-to status are related to } \\
\text { individual investments in financial, social } \\
\text { station, and academic dimensions. }\end{array}$ & $\begin{array}{c}\text { Cross } \\
\text { sectional data }\end{array}$ & $\begin{array}{l}\text { Two data sets were used: Set 1-The } \\
\text { women's dataset from } 2,734 \\
\text { households surveyed from five } \\
\text { states in North India. Set } 2-3,723 \\
\text { children from } 1,749 \text { households. }\end{array}$ & $\begin{array}{l}\text { Reference groups were important correlates of aspiration formation in some cases, } \\
\text { and aspirations for assets and social status were influenced by those who were } \\
\text { "wealthier" or more socially connected, respectively. }\end{array}$ \\
\hline 14. & $\begin{array}{l}\text { Beaman, Duflo, } \\
\text { Pande, and Topalova } \\
\text { (2012) } \\
\text { India }\end{array}$ & $\begin{array}{l}\text { To demonstrate that female leadership influences } \\
\text { adolescent girls' career aspirations and academic } \\
\text { attainment. }\end{array}$ & $\begin{array}{c}\text { Cross } \\
\text { sectional data }\end{array}$ & $\begin{array}{l}\text { Randomized natural experiment is } \\
\text { employed. } 8,453 \text { adolescents, aged } \\
11-15 \text {, and their parents in } 495 \\
\text { villages surveyed }\end{array}$ & $\begin{array}{l}\text { Farm parents had higher aspirations for boys than for girls. Female leadership } \\
\text { influenced young girls' career aspirations and educational fulfillment, such that the } \\
\text { gender gap in adoloscent academic attainment was removed, and girls spent less } \\
\text { time on household work. }\end{array}$ \\
\hline 15. & $\begin{array}{l}\text { Elias et al. (2018) } \\
\text { Mali, Malawi, } \\
\text { Morocco, Mexico, } \\
\text { India, Nigeria, and } \\
\text { the Philippines }\end{array}$ & $\begin{array}{l}\text { To analyze rural young men's and women's } \\
\text { occupational aspirations and trajectories. }\end{array}$ & $\begin{array}{c}\text { Cross } \\
\text { sectional } \\
\text { qualitative } \\
\text { data }\end{array}$ & $\begin{array}{l}25 \text { case studies from the global } \\
\text { comparative study 'GENNOVATE. } \\
\text { Qualitative data from } 50 \text { sex- } \\
\text { segregated focus groups. }\end{array}$ & $\begin{array}{l}\text { Different gender norms that discriminated against women in agriculture discouraged } \\
\text { young women from aspiring to agriculture-related occupations. } \\
\text { Results showed that youth and gender issues are inextricably linked and cannot be } \\
\text { understood in isolation. }\end{array}$ \\
\hline 16. & $\begin{array}{l}\text { Bernard, Dercon, and } \\
\text { Taffesse (2011) } \\
\text { Ethiopia }\end{array}$ & $\begin{array}{l}\text { To explore whether fatalistic beliefs affect the } \\
\text { behavior and attitude of poor rural households } \\
\text { towards investment for the future. }\end{array}$ & $\begin{array}{c}\text { Cross } \\
\text { sectional } \\
\text { qualitative } \\
\text { data. }\end{array}$ & $\begin{array}{l}1,192 \text { households from } 54 \text { villages } \\
\text { (-24 households per village) }\end{array}$ & $\begin{array}{l}\text { The study found evidence of fatalistic beliefs among a considerable number of rural } \\
\text { households, and also indicators of aspiration gaps and low self-efficacy. Such } \\
\text { beliefs consistently correlated with lower demand for credit, in terms of loan size, } \\
\text { repayment horizon, and productive purposes. }\end{array}$ \\
\hline 17. & $\begin{array}{l}\text { Bernard, Taffesse, } \\
\text { and Dercon (2008) } \\
\text { Ethiopia }\end{array}$ & $\begin{array}{l}\text { To determine whether a more systematic and } \\
\text { rigorous analysis using this framework is } \\
\text { needed, Particularly, we used recently collected } \\
\text { data in rural Ethiopia to look at whether we } \\
\text { will uncover basic correlations predicted by the } \\
\text { aspiration failure framework. }\end{array}$ & $\begin{array}{c}\text { Cross } \\
\text { sectional } \\
\text { qualitative } \\
\text { data. }\end{array}$ & $\begin{array}{l}24 \text { households per village; } 54 \\
\text { villages in nine districts }\end{array}$ & $\begin{array}{l}\text { The size of the gap between individual economic behavior directly corresponded } \\
\text { with the relevant aspiration gap, which, in turn, was determined by social and } \\
\text { individual factors. }\end{array}$ \\
\hline \multicolumn{6}{|c|}{ Aspirations and poverty } \\
\hline 18. & $\begin{array}{l}\text { Kosec, Khan, } \\
\text { Taffesse, and Tadesse } \\
\text { (2014b) } \\
\text { Ethiopia and Pakistan }\end{array}$ & $\begin{array}{l}\text { To understand the role of weather calamities on } \\
\text { the aspirations of rural people. }\end{array}$ & Panel data & $\begin{array}{l}\text { Randomized field experiments. } \\
\text { Seven rounds of panel data as input. }\end{array}$ & $\begin{array}{l}\text { Negative weather shocks undoubtedly lowered the forward-looking aspirations of } \\
\text { the poor. The double burden of such shocks depleted the poor's existing income } \\
\text { and assets, and then lowered their aspirations for the future. }\end{array}$ \\
\hline 19. & $\begin{array}{l}\text { Kosec and Mo (2017) } \\
\text { Pakistan }\end{array}$ & $\begin{array}{l}\text { To determine, firstly, whether natural disasters } \\
\text { affect aspirations and, secondly, if they do, } \\
\text { whether governments can lessen the impacts. }\end{array}$ & Panel data & $\begin{array}{l}\text { 2,090 rural households panel survey } \\
\text { data. Two rounds of data is used. }\end{array}$ & $\begin{array}{l}\text { Natural calamities had a negative effect on aspirations, particularly for the poor, but } \\
\text { these negative impacts could be reduced by the government's social protection } \\
\text { programs. }\end{array}$ \\
\hline \multicolumn{6}{|c|}{ Boosting aspirations for resilience among the rural poor } \\
\hline 20. & $\begin{array}{l}\text { Tanguy, Dercon, } \\
\text { Orkin, and Taffesse } \\
\text { (2014) } \\
\text { Ethiopia }\end{array}$ & $\begin{array}{l}\text { To test whether aspirations and future-oriented } \\
\text { behavior can be altered using an innovative } \\
\text { experimental design. }\end{array}$ & Panel data & $\begin{array}{l}\text { Innovative experimental design. } 64 \\
\text { villages randomly selected from the } \\
\text { list of villages. Total of } 2063 \\
\text { individuals of which } 1034 \text { received } \\
\text { treatment and } 1029 \text { are placebo. }\end{array}$ & $\begin{array}{l}\text { Aspirations changed among the treated individuals, but did not change in the } \\
\text { control groups. The effects were substantial for those with higher aspirations at } \\
\text { baseline. }\end{array}$ \\
\hline 21. & $\begin{array}{l}\text { Kosec, Hameed, and } \\
\text { Hausladen (2012) } \\
\text { Pakistan }\end{array}$ & $\begin{array}{l}\text { To examine how aspirations, vary across } \\
\text { different types of individuals households in rural } \\
\text { Pakistan, and determine average aspiration } \\
\text { levels. To also identify: which intrinsic and } \\
\text { extrinsic determinants, including cognitive } \\
\text { processes, help to form aspirations; which types } \\
\text { of policies and programs might help to raise } \\
\text { aspirations; and the possible advantages of } \\
\text { raising aspiration levels. }\end{array}$ & $\begin{array}{c}\text { Cross } \\
\text { sectional data }\end{array}$ & $\begin{array}{l}5,00 \text { individuals as part of a } \\
\text { comprehensive household survey. }\end{array}$ & $\begin{array}{l}\text { Aspirations differed among women and men, the uneducated and educated, and } \\
\text { agricultural wage laborers and non-farm workers. Furthermore, different internal } \\
\text { factors were strongly correlated with aspiration levels. Some groups in particular } \\
\text { were most at risk of aspiration failure. }\end{array}$ \\
\hline 22. & $\begin{array}{l}\text { Agarwal and Agrawal } \\
\text { (2016) } \\
\text { India }\end{array}$ & $\begin{array}{l}\text { To determine whether farmers farm out of choice } \\
\text { or a lack of options. To also identify what } \\
\text { distinguishes farmers who like cultivation from } \\
\text { people who do not, by examining whether } \\
\text { preference is down to their household and private } \\
\text { characteristics and endowments, the local } \\
\text { ecology and regional economy, or a combination } \\
\text { of these and other factors. }\end{array}$ & Panel data & $\begin{array}{l}51,770 \text { rural households, involving } \\
286,503 \text { individuals dwelling in } \\
6,638 \text { villages throughout India; } \\
\text { stratified multi-stage sampling }\end{array}$ & $\begin{array}{l}\text { Women tended to dislike farming more than men, which given the feminization of } \\
\text { agriculture raises further concerns. Vulnerable farmers need to be helped to } \\
\text { overcome production constraints, so that they begin to see farming as a viable } \\
\text { profession or exit on their onn terms rather than out of distress. It was also oted that } \\
\text { increasing farm productivity had the most potential for reducing rural poverty. }\end{array}$ \\
\hline \multicolumn{6}{|c|}{ Measuring aspirations } \\
\hline $\mathrm{i}$ & $\begin{array}{l}\text { Bernard and Taffesse } \\
\text { (2014) } \\
\text { Ethiopia }\end{array}$ & $\begin{array}{l}\text { To design an instrument for measuring } \\
\text { aspirations. }\end{array}$ & Panel data & 155 individuals in 16 villages & $\begin{array}{l}\text { A standard instrument was designed to provide a usable, valid, and reliable method } \\
\text { to measure aspirations within standard surveys. }\end{array}$ \\
\hline ii & $\begin{array}{l}\text { Bernard and Taffesse } \\
\text { (2012) } \\
\text { India }\end{array}$ & $\begin{array}{l}\text { To show how female leadership influences } \\
\text { adolescent girls' professional aspirations and } \\
\text { academic attainment. }\end{array}$ & $\begin{array}{c}\text { Cross } \\
\text { sectional data }\end{array}$ & $\begin{array}{l}\text { Randomized natural experiment is } \\
\text { employed. } 8,453 \text { adolescents, aged } \\
11-15 \text {, and their parents in } 495 \\
\text { villages surveyed }\end{array}$ & $\begin{array}{l}\text { Female leadership influenced young girls" career aspirations and educational } \\
\text { fulfillment. Farm parents had higher aspirations for boys than for girls. The gender } \\
\text { gap in adolescent academic attainment was deleted, and girls spent less time on } \\
\text { household work. }\end{array}$ \\
\hline
\end{tabular}

Acknowledgements We would like to thank Dr Michael Hauser, Theme Leader-MIND and Principal Scientist at ICRISAT, Innovation Systems for the Drylands Program, Ethiopia; and the Publication Department at ICRISAT for initially reviewing the article and proofreading an earlier version of this article.

Funding This work was undertaken as part of the CGIAR Research Program on Water, Land and Ecosystems (WLE) led by International Water Management Institute (IWMI) and Grain Legumes and Dryland Cereals (GLDC) led by International Crops Research Institute for the Semi-Arid Tropics (ICRISAT). Funding support for this study was provided by Global Challenge Research Fund (GCRF) under Funding Body Grant Ref: BB/P027970/1, Lead Party Ref: RG88282 as part of the Transforming India's Green Revolution by Research and Empowerment for Sustainable food Supplies (TIGR2ESS) project under Flagship 1 'Sustainable and Transformative Agrarian and Rural Trajectories (START)' (https://tigr2ess. globalfood.cam.ac.uk/fps/FP1). The opinions mentioned in this article are not the official opinions of the WLE, GLDC, GCRF, and no donors were involved in the research, the collection, analysis and interpretation of data, or the preparation of this review article. It is the authors decision to submit the article for publication in the European Journal of Development Research. 


\section{Declarations}

Conflict of interest The authors declare that they have no conflict of interest.

Open Access This article is licensed under a Creative Commons Attribution 4.0 International License, which permits use, sharing, adaptation, distribution and reproduction in any medium or format, as long as you give appropriate credit to the original author(s) and the source, provide a link to the Creative Commons licence, and indicate if changes were made. The images or other third party material in this article are included in the article's Creative Commons licence, unless indicated otherwise in a credit line to the material. If material is not included in the article's Creative Commons licence and your intended use is not permitted by statutory regulation or exceeds the permitted use, you will need to obtain permission directly from the copyright holder. To view a copy of this licence, visit http://creativecommons.org/licenses/by/4.0/.

\section{References}

Agarwal, B., and A. Agrawal. 2016. To farm or not to farm? Indian farmers in transition (GDI Working Paper 2016-001). The University of Manchester. Available at: https://hummedia.manchester.ac.uk/ institutes/gdi/publications/workingpapers/GDI/GDI_WP2016001_Agarwal_Agrawal_final.pdf

Anyidoho, N.A., J. Leavy, and K. Asenso-Okyere. 2012. Perceptions and Aspirations: A Case Study of Young People in Ghana's Cocoa Sector (IDS bulletin-institute of development studies, 43(6, SI), 20-32). https://doi.org/10.1111/j.1759-5436.2012.00376.x

Appadurai, A. 2004. The capacity to aspire. Culture and Public Action, 59-84.

BBC. 2019. The Ageing Crisis Threatening Farming. Follow the Food, BBC Future and BBC World News: http://www.bbc.com/future/bespoke/follow-the-food/the-ageing-crisis-threatening-farming/

Beaman, L., E. Duflo, R. Pande, and P. Topalova. 2012. Female leadership raises aspirations and educational attainment for girls: A policy experiment in India. Science 335 (6068): 582-586. https://doi.org/10. 1126/science. 1212382 .

Bell, A.R., P.S. Ward, M. Ashfaq, and S. Davies. 2017. Can Agricultural Aspirations Influence Preferences for New Technologies. IFPRI Discussion Paper 1636. Washington, D.C.: International Food Policy Research Institute (IFPRI). Retrieved from http://ebrary.ifpri.org/cdm/ref/collection/p15738coll2/id/ 131156

Bernard, T., A.S. Taffesse, and S. Dercon. 2008. Aspirations failure and well-being outcomes in Ethiopia: Towards an empirical exploration (iiG Workshop, Oxford University, 21 March 2008. 28 pp.). Retrieved from https:/www.gov.uk/dfid-research-outputs/aspirations-failure-and-well-being-outcomesin-ethiopia-towards-an-empirical-exploration\#citation

Bernard, T., S. Dercon, and A.S. Taffesse. 2011. Beyond fatalism-an empirical exploration of self-efficacy and aspirations failure in Ethiopia (ESSP working paper 46). Retrieved from https://www.ifpri.org/ publication/beyond-fatalism-empirical-exploration-self-efficacy-and-aspirations-failure-ethiopia

Bernard, T., and A.S. Taffesse. 2012. Measuring aspirations: Discussion and example from Ethiopia (International Food Policy Research Institute Discussion Paper, 01190). Retrieved from https://ebrary.ifpri. org/digital/collection/p15738coll2/id/127274/

Bernard, T., and A.S. Taffesse. 2014. Aspirations: An approach to measurement with validation using Ethiopian data. Journal of African Economies 23 (2): 189-224. https://doi.org/10.1093/jae/ejt030.

Bowles, S., H. Gintis, and M.O. Groves. 2005. Unequal chances: Family background and economic success. Princeton: Princeton University Press.

Camerer, C., L. Babcock, G. Loewenstein, and R. Thaler. 1997. Labor supply of New York City cabdrivers: One day at a time. The Quarterly Journal of Economics 112 (2): 407-441.

Crossland, M., A.M. Paez Valencia, T. Pagella, K. Mausch, D. Harris, L. Dilley, and L. Winowiecki. 2021. Women's changing opportunities and aspirations amid male outmigration: Insights from Makueni County, Kenya. The European Journal of Development Research. https://doi.org/10.1057/ s41287-021-00362-8.

Dalton, P.S., S. Ghosal, and A. Mani. 2015. Poverty and aspirations failure. The Economic Journal 126 (590): 165-188. https://doi.org/10.2139/ssrn.1975339. 
DFID. 2014. How to Note: Assessing the Strength of Evidence.GOV.UK. https://www.gov.uk/government/ publications/how-to-note-assessing-the-strength-of-evidence. Accessed 19 Mar 2014.

Dilley, L., K. Mausch, M. Crossland, and D. Harris. 2021. What's the Story on Agriculture ? Using Narratives to Understand Farming Households ' Aspirations in Meru , Kenya. The European Journal of Development Research. https://doi.org/10.1057/s41287-021-00361-9

Duflo, E. 2013. Hope, aspirations and the design of the fight against poverty. Arrow Lectures.. https://www.Ethicsinsociety.Stanford. Edu/Events/Lectures/Arrow-Lectures/ Esther-Duflo-Hopeaspirations-and-the-Design-of-the-Fight-against.

Elias, M., N. Mudege, D.E. Lopez, D. Najjar, V. Kandiwa, J. Luis, et al. 2018. Gendered aspirations and occupations among rural youth, in agriculture and beyond: A cross-regional perspective. Journal of Gender, Agriculture and Food Security. https://doi.org/10.19268/JGAFS.312018.4.

FAO. 2014. Food Security for Sustainable Development and Urbanization: Contribution to the United Nations Economic and Social Council Integration Segment, FAO, Rome. https://www.un.org/en/ ecosoc/integration/pdf/foodandagricultureorganization.pdf

FAO. 2020. The state of food and agriculture: Migration, agriculture and rural development. Rome. http:// www.fao.org/3/I9549EN/i9549en.pdf. Accessed 18 May 2020

Genicot, G., and D. Ray. 2017. Aspirations and inequality. Econometrica 85 (2): 489-519. https://doi.org/10. 3982/ECTA13865.

Giuliani, A., S. Mengel, C. Paisley, N. Perkins, I. Flink, O. Oliveros, and M. Wongtschowski. 2017. Realities, perceptions, challenges and aspirations of rural youth in dryland agriculture in the Midelt Province, Morocco. Sustainability 9 (6): 871. https://doi.org/10.3390/su9060871.

Jacqueline, S., Jane Nolan, Ingrid Schoon, Andy Ross, and Peter Martin. 2007. Science Related Careers: Aspirations and Outcomes in Two British Cohort Studies. Equal Opportunities International. https:// doi.org/10.1108/02610150710732203

Jöhr, H. 2012. Where are the future farmers to grow our food? International Food and Agribusiness Management Review 15: 9-11.

Kale, R.B., K. Ponnusamy, A. Chakravarty, R. Sendhil, and A. Mohammad. 2018. Future aspirations and planning of dairy farmers in India: Horizon 2020. Indian Journal of Animal Sciences 88 (4): 101-106.

Kosec, K., M. Hameed, and S. Hausladen. 2012. Aspirations in rural Pakistan: An empirical analysis (PSSP Working Paper 9). Washington, D.C.: International Food Policy Research Institute (IFPRI). Retrieved from http://ebrary.ifpri.org/cdm/ref/collection/p15738coll2/id/127372

Kosec, K., and H. Khan. 2017. Understanding the Aspirations of the Rural Poor. In D.J. Spielman, S.J. Malik, P. Dorosh, \& N. Ahmad (Eds.), Agriculture and the Rural Economy in Pakistan. University of Pennsylvania Press. https://doi.org/10.9783/9780812294217-014

Kosec, K., H. Khan, A.S. Taffesse, and F. Tadesse. 2014a. Addressing weather shocks: Promoting resilient aspirations for the rural poor. 2020 Conference Brief 19. May 17-19, Addis Ababa, Ethiopia. Washington, D.C.: International Food Policy Research Institute (IFPRI). http://ebrary.ifpri.org/cdm/ref/colle ction/p15738coll2/id/128138

Kosec, K., Khan, H., Taffesse, A.S., \& Tadesse, F. 2014b. Promoting aspirations for resilience among the rural poor. In Resilience for food and nutrition security. Eds. Fan, Shenggen; Pandya-Lorch, Rajul and Yosef, Sivan. Chapter 11. pp. 91-98. Washington, D.C.: International Food Policy Research Institute (IFPRI). http://ebrary.ifpri.org/cdm/ref/collection/p15738coll2/id/128448

Kosec, K., Khan, H., Spielman, D., Malik, S., Dorosh, P., \& Ahmad, N. 2016. Understanding the aspirations of the rural poor. Agriculture and Rural Poverty Reduction in Pakistan. Spielman, David J.; Malik, Sohail Jehangir; Dorosh, Paul A.; and Ahmad, Nuzhat (Eds.). Chapter 11. Pp. 433-474. Philadelphia, PA: University of Pennsylvania Press on behalf of the International Food Policy Research Institute (IFPRI). https://www.ifpri.org/publication/understanding-aspirations-rural-poor

Kosec, K., and C.H. Mo. 2017. Aspirations and the role of social protection: Evidence from a natural disaster in rural Pakistan. World Development 97: 49-66. https://doi.org/10.1016/j.worlddev.2017.03.039.

Kosec, K., and J. Song. 2018. Aspirations and women's empowerment: Evidence from Kyrgyzstan (IFPRI Discussion Paper 1786). Washington, DC: International Food Policy Research Institute (IFPRI). http:// ebrary.ifpri.org/cdm/ref/collection/p15738coll2/id/133033

LaRue, K., T. Daum, K. Mausch, and D. Harris. 2021. Who wants to farm? Answers depend on how you ask: A case study on youth aspirations in Kenya. European Journal of Development Research. https://doi. org/10.1057/s41287-020-00352-2.

Leavy, J., and N. Hossain. 2014. Who wants to farm? Youth aspirations, opportunities and rising food prices (IDS Working Papers, 2014(439), 1-44. doi:https://doi.org/10.1111/j.2040-0209.2014.00439.x 
Maertens, A. 2011. Does education pay off? Subjective expectations on education in rural India. Economic and Political Weekly, 58-63. https://www.epw.in/journal/2011/09/special-articles/does-education-paysubjective-expectations-education-rural-india

Mausch, K., D. Harris, E. Heather, E. Jones, J. Yim, and M. Hauser. 2018. Households' aspirations for rural development through agriculture. Outlook on Agriculture (TSI) 47 (2): 108-115 .

Mo, C.H.J. 2012. Essays in Behavioral Political Economy: The Effects of Affect, Attitudes, and Aspirations (Doctoral dissertation, Stanford University). Available at https://searchworks.stanford.edu/view/ 9623096

Nag, A., S.K. Jha, A. Mohammad, S. Maiti, J. Gupta, D.K. Gosain, K.K. Datta, and T.K. Mohanty. 2018. Predictive factors affecting Indian rural farm youths' decisions to stay in or leave agriculture sector. Journal of Agricultural Science and Technology 20 (2): 221-234.

Pachauri, S. 2019. The invisibility of gender in Indian agriculture. DownToEarth. https://www.downtoearth. org.in/blog/agriculture/the-invisibility-of-gender-in-indian-agriculture-63290. Accessed 19 Feb 2019.

Press Information Bureau, \& Government of India. 2018. Agricultural mechanization picks up pace. Retrieved from http://www.pib.nic.in/Pressreleaseshare.aspx?PRID=1518097

Raghunathan, K., A.R. Quisumbing, N. Kumar, and K. Cunningham. 2018. Women's aspirations for the future, and their financial, social and educational investments (IFPRI Discussion Paper 1752). Washington, DC: International Food Policy Research Institute (IFPRI). Retrieved from http://ebrary.ifpri.org/ $\mathrm{cdm} /$ singleitem/collection/p15738coll2/id/132792

Ray, D. 2006. Aspirations, poverty, and economic change. Understanding Poverty 1: 409-421.

Riley, E. 2017. Increasing students' aspirations: the impact of Queen of Katwe on students' educational attainment (CSAE Working Paper WPS/2017-13). Retrieved from https://pacdev.ucdavis.edu/files/ conference-schedule/session/papers/3E/Riley.pdf

Rietveld, A.M., M. van der Burg, and J.C. Groot. 2020. Bridging youth and gender studies to analyse rural young women and men's livelihood pathways in Central Uganda. Journal of Rural Studies. https://doi. org/10.1016/j.jrurstud.2020.01.020.

Rukmini, S. 2013. Farmer population falls by 9 million in 10 years. Times of India https://timesofindia.india times.com/india/Farmer-population-falls-by-9-million-in-10-years/articleshow/19813617.cms

Shandilya, T.S., B.K. Chaturvedi, and D.K. Suryawanshi. 2017. Level of aspiration of tribal youths regarding different on-farm and off-farm activities. Plant Archives 17 (2): 1508-1510.

Tanguy, B., S. Dercon, K. Orkin, and A.S. Taffesse. 2014. The Future in Mind: Aspirations and ForwardLooking Behaviour in Rural Ethiopia (CSAE Working Paper Series 2014-16). Centre for the Study of African Economies, University of Oxford. https://ideas.repec.org/p/csa/wpaper/2014-16.html

Tekale, V.S., M.D. Mali, and J.I. Shaikh. 2015. Aspirations of rural youth towards self-development. Advance Research Journal of Social Science 6 (1): 36-41. https://doi.org/10.15740/HAS/ARJSS/6.1/36-41.

Viswanatha, H., B.N. Manjunatha, and M.T. Lakshminarayan. 2014. Aspirations and problems of rural youth practising agriculture. Mysore Journal of Agricultural Sciences 48 (4): 583-588.

UNDESA .2018. Policies on population ageing. United Nations Department of Economic and Social Affairs. https://www.un.org/en/development/desa/population/publications/pdf/policy/Infochart_ageing_polic ies_14Nov2018.pdf

Verkaart, S., K. Mausch, and D. Harris. 2018. Who are those people we call farmers? Rural Kenyan aspirations and realities. Development in Practice 28 (4): 468-479. https://doi.org/10.1080/09614524.2018. 1446909.

World Bank. 2017. Women in Agriculture: The Agents of Change for the Global Food System. The World Bank. Available at https://www.worldbank.org/en/news/feature/2017/03/07/women-in-agric ulture-the-agents-of-change-for-the-food-system

Yeboah, F.K., and T.S. Jayne. 2018. Africa's evolving employment trends. Journal of Development Studies 54 (5): 803-832.

Yosef, S., A.D. Jones, B. Chakraborty, and S. Gillespie. 2015. Agriculture and nutrition in Bangladesh: Mapping evidence to pathways. Food and Nutrition Bulletin 36 (4): 387-404. https://doi.org/10.1177/03795 72115609195 .

Zou, B., A.K. Mishra, and B. Luo. 2018. Aging population, farm succession, and farmland usage: Evidence from rural China. Land Use Policy 77: 437-445.

Publisher's Note Springer Nature remains neutral with regard to jurisdictional claims in published maps and institutional affiliations. 